\title{
Macroelements in the surface microlayer of water of urban ponds
}

\author{
Józef Piotr Antonowicz ${ }^{1}$, Jacek Kubiak², Sylwia Machula² \\ ${ }^{1}$ Department of Environmental Chemistry, Pomeranian Academy in Słupsk, Arciszewskiego 22b, 76-200 Słupsk \\ e-mail: jozef.antonowicz@apsl.edu.pl (corresponding author)
}

${ }^{2}$ Department of Hydrochemistry and Aquatic Biological Resources, West Pomeranian University of Technology, Kazimierza Królewicza 4, 71-550 Szczecin, Poland, e-mail: jacek.kubiak@zut.edu.pl, sylwia.machula@zut.edu.pl

\begin{abstract}
Analyses were conducted concerning the accumulation of four metals representing the group of macroelements, i.e. sodium, potassium, calcium and magnesium in two ponds located in the city of Słupsk. Water samples for chemical analyses were collected from the surface microlayer using a Garrett net. At the same time subsurface water samples were collected. Concentrations of metals were determined using a mass spectrometer. Generally, amounts of sodium, potassium, calcium and magnesium were similar in surface microlayer and subsurface water. Only in the case of potassium and calcium was low enrichment observed in the surface microlayer in one pond, while the greatest extent for magnesium enrichment was observed in the spring period.
\end{abstract}

Key words: pond, surface microlayer, macroelements

\section{Introduction}

The air-water interface is the surface microlayer $(S M L)$ found at the interface of two environments: the hydrosphere and the atmosphere (Norkrans 1980; Cunliffe and Murrell 2009). The SML covers the surface of all water bodies, which accounts for $71 \%$ Earth's surface area. The $S M L$ is the physical boundary between the hydrosphere and the atmosphere. Roughly considered to be the uppermost $1 \mathrm{~mm}$ of the hydrosphere, the $S M L$ is physically and chemically distinct when compared with the subsurface water (Liss and Duce 2005). The SML is a zone of matter and energy exchange between the hydrosphere and the atmosphere. It is a habitat for neustonic organisms. It exhibits specific physical, chemical and biological properties (Hillbricht-Ilkowska and Kostrzewska-Szlakowska 2004; Cunliffe and Murrell 2009; Antonowicz et al. 2015). The presence of the surface film and surface tension properties means that the seasurface microlayer is a unique habitat that is often referred to as the neuston (Liss and Duce 2005). The SML is characteristically enriched with organic compounds, such as lipids, proteins and polysaccharides (Liss and Duce 2005), herbicides and heavy metals (Wurl and Obbard 2004). However, not all chemical substances exhibit this accumulation ability. Such substances as $\mathrm{Ca}$ and $\mathrm{Mg}$ are typically accumulated to a limited extent or only periodically. According to Antonowicz (2015), periodical $\mathrm{Mg}$ enrichment in $S M L$ from Lake Dołgie Wielkie was probably connected with accumulation in the phytoneuston chloroplasts.

The aim of this study was to investigate the capacity of the surface microlayer of urban ponds to accumulate $\mathrm{Na}, \mathrm{K}, \mathrm{Ca}$ and $\mathrm{Mg}$ to determine their concentrations in $S M L$ and $S U B$ (subsurface layer) by mass spectrometry; and to investigate seasonal variation in the concentrations of these macroelements in SML and $S U B$ in the analysed ponds.

\section{Materials and methods}

The analyses were conducted on two ponds located in the city of Słupsk in urban green areas in the vicinity of busy roads. One pond is located in the vicinity of Arciszewskiego Street, while the other pond is situated at Kaszubska Street (Fig. 1). The ponds differ greatly in terms of water surface area (pond 1 has an area of approx. $2.8 \mathrm{ha}$, while pond 2 has an area of approx. 0.15 ha). Samples from the ponds were collected from October 2007 to September 2008. The ponds are located in the vicinity of the River Słupia, which flows through the city. Samples of the surface microlayer $(S M L)$ (thick- 

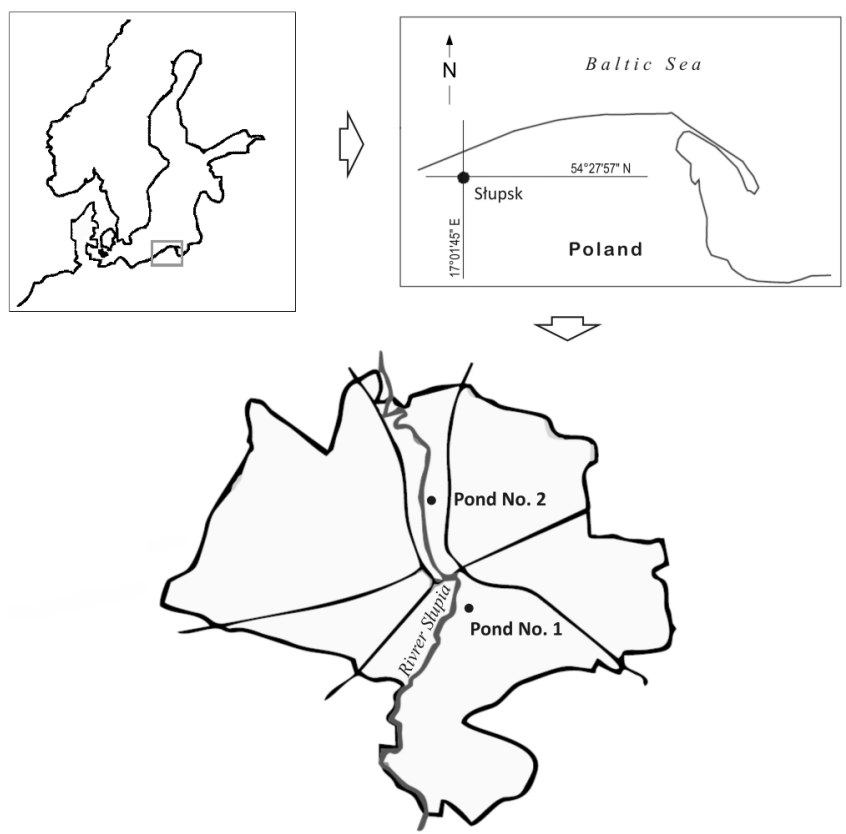

Fig. 1. Location of analysed ponds

ness $242 \mu \mathrm{m} \pm 40$ ) were collected with a Garrett net (Garrett 1965), while samples of the subsurface layer (SUB) were taken at a depth of about $10-15 \mathrm{~cm}$. For chemical analyses samples were collected in PET containers, which were pickled in $\mathrm{HNO}_{3}$ and rinsed with demineralized water.

\section{Chemical and statistical analyses}

The concentrations of metals, i.e. $\mathrm{Ca}, \mathrm{Mg}, \mathrm{K}$ and $\mathrm{Na}$, were determined using a Perkin Elmer Elan DRC-e mass spectrometer. Water samples were mineralized in trace pure nitric acid V (Merck, Darmstadt, Germany). Correction formulas were applied to introduce adjustments for the presence of compounds forming unstable bonds with a molecular mass equivalent to those of assayed elements (Perkin Elemer Sciex 2005). These results were then compared sequentially for each metal separately with the reference standard samples (Perkin Elmer) with the instrument controlled by the ELAN Perkin Elmer SCIEX Instrument Control software. As a blank sample, the sample obtained from the water deionizer (Hydrolab company) was used. The recovery rate of the standard added to samples was determined, ranging from 91.2 to $114.3 \%$. In order to verify the accuracy of the method, a reference material, ES-L-1 (Ground Water, EnviroMAT) was used.

\section{Statistical analysis}

In order to compare the investigated layers, i.e. surface microlayer and subsurface water, we applied average enrichment factors according to the following formula:

$$
E F=C_{S M L} / C_{S U B}
$$

where: $C_{S M L}$ and $C_{S U B}$ are concentrations of analysed metals (Estep et al. 1985) calculated partly from each measurement from $S M L_{i}$ and $S U B_{i}$.

Statistical analyses such as the Shapiro-Wilk normality test, mean, median, minimum, maximum, standard deviation and Spearman or Pearson correlations were calculated (Statsoft 2012; Luszniewicz and Słaby 2008).

\section{Results}

Tables 1 and 2 present data on the concentrations of $\mathrm{Na}, \mathrm{K}, \mathrm{Ca}$ and $\mathrm{Mg}$ and statistical parameters describing them for the SML and SUB collected from the two ponds located in the city of Słupsk. The analysis of data given in the tables shows that in pond No. 1 concentrations of $\mathrm{Na}, \mathrm{K}$ and $\mathrm{Ca}$ in the $S U B$ layer were greater than in pond No.2, whereas the situation was opposite in the case of Mg. Mean concentrations in SUB in ponds No. 1 and No. 2 were as follows: $\mathrm{Na}-19.1 \mathrm{mg} \mathrm{dm}^{-3}$ and 11.3 $\mathrm{mg} \mathrm{dm}{ }^{-3}, \mathrm{~K}-2.8 \mathrm{mg} \mathrm{dm}^{-3}$ and $1.3 \mathrm{mg} \mathrm{dm}^{-3}, \mathrm{Mg}-6.6$ $\mathrm{mg} \mathrm{dm}{ }^{-3}$ and $7.6 \mathrm{mg} \mathrm{dm}^{-3}, \mathrm{Ca}-60.6 \mathrm{mg} \mathrm{dm}^{-3}$ and 52.1 $\mathrm{mg} \mathrm{dm}{ }^{-3}$. In $S M L$ greater concentrations were recorded in pond No.1 for $\mathrm{Na}, \mathrm{K}$ and $\mathrm{Mg}$, while for Ca the concentration was greater in pond No.2. Mean concentrations of the analysed elements in SML and SUB were ordered according to the increasing concentrations as follows: $\mathrm{K}<\mathrm{Mg}<\mathrm{Na}<\mathrm{Ca}$.

The capacity to enrich the surface microlayer varied in both these ponds. Obtained enrichment factors were low. In pond No. 1 concentrations of $\mathrm{Ca}, \mathrm{Mg}, \mathrm{K}$ and $\mathrm{Na}$ were comparable in $S M L$ and $S U B$, with the obtained enrichment factors $(E F)$ falling within the range of 0.99 for K to 1.11 for Na. In pond No. 2 the recorded concentrations for $\mathrm{Mg}$ and $\mathrm{Na}$ were comparable with

Table 1. Statistical parameters of studied metals in the surface microlayer and subsurface water of Pond No. 1 (near Arciszewskiego St.)

\begin{tabular}{llcccc}
\hline & & $\mathrm{Na}$ & $\mathrm{K}$ & $\mathrm{Mg}$ & $\mathrm{Ca}$ \\
\hline \multirow{3}{*}{ SML } & Mean & 20.3 & 3.0 & 7.7 & 61.0 \\
\cline { 2 - 6 } & Maximum & 77.4 & 8.2 & 29.8 & 141.9 \\
\cline { 2 - 6 } & Minimum & 7.7 & 0.7 & 2.0 & 13.2 \\
\cline { 2 - 6 } & Median & 15.8 & 1.1 & 4.8 & 50.1 \\
\cline { 2 - 6 } & SD & 20.4 & 3.3 & 8.3 & 44.9 \\
\hline \multirow{2}{*}{ SUB } & Mean & 19.1 & 2.8 & 6.6 & 60.6 \\
\cline { 2 - 6 } & Maximum & 75.2 & 6.7 & 18.5 & 166.2 \\
\cline { 2 - 6 } & Minimum & 8.4 & 0.7 & 2.6 & 16.7 \\
\cline { 2 - 6 } & Median & 13.9 & 1.6 & 4.6 & 42.5 \\
\cline { 2 - 6 } & SD & 19.9 & 2.3 & 4.9 & 48.0 \\
\hline \multirow{2}{*}{ EF } & $E F$ & 1.11 & 0.99 & 1.06 & 1.02 \\
\hline
\end{tabular}


Table 2. Statistical parameters of studied metals in the surface microlayer and subsurface water of Pond No. 2 (near Kaszubska St.)

\begin{tabular}{clcccc}
\hline & & $\mathrm{Na}$ & $\mathrm{K}$ & $\mathrm{Mg}$ & $\mathrm{Ca}$ \\
\hline \multirow{4}{*}{ SML } & Mean & 13.5 & 1.7 & 10.1 & 67.2 \\
\cline { 2 - 6 } & Maximum & 17.9 & 5.1 & 38.7 & 179.2 \\
\cline { 2 - 6 } & Minimum & 7.7 & 0.7 & 2.6 & 32.7 \\
\cline { 2 - 6 } & Median & 14.0 & 1.3 & 6.2 & 46.5 \\
\cline { 2 - 6 } & SD & 3.5 & 1.3 & 10.7 & 51.0 \\
\hline \multirow{3}{*}{ SUB } & Mean & 11.3 & 1.3 & 7.6 & 52.1 \\
\cline { 2 - 6 } & Maximum & 16.1 & 3.4 & 24.0 & 154.7 \\
\cline { 2 - 6 } & Minimum & 2.4 & 0.6 & 1.9 & 29.3 \\
\cline { 2 - 6 } & Median & 11.9 & 0.8 & 5.2 & 40.4 \\
\cline { 2 - 6 } & SD & 4.0 & 0.9 & 6.2 & 35.7 \\
\hline EF & EF & 1.15 & 1.34 & 1.06 & 1.24 \\
\hline
\end{tabular}

those in $S M L$ and amounted to $E F=1.06-1.15$, while for $\mathrm{Ca}$ and $\mathrm{K}$ enrichment was found at $E F=1.24-1.34$.

Seasonal variation was observed for the analysed chemicals. Figure 2 presents the seasonal dynamics for $\mathrm{Na}$ and $\mathrm{K}$ concentrations in the $S M L$ and $S U B$ of these ponds. In the spring in pond No. 1 sodium concentration was almost 3-fold greater in SML and than in SUB the other seasons. In turn, in pond No. 2 the greatest concentration was observed in $S M L$ and $S U B$ in the winter, while it was lowest in the autumn. In the case
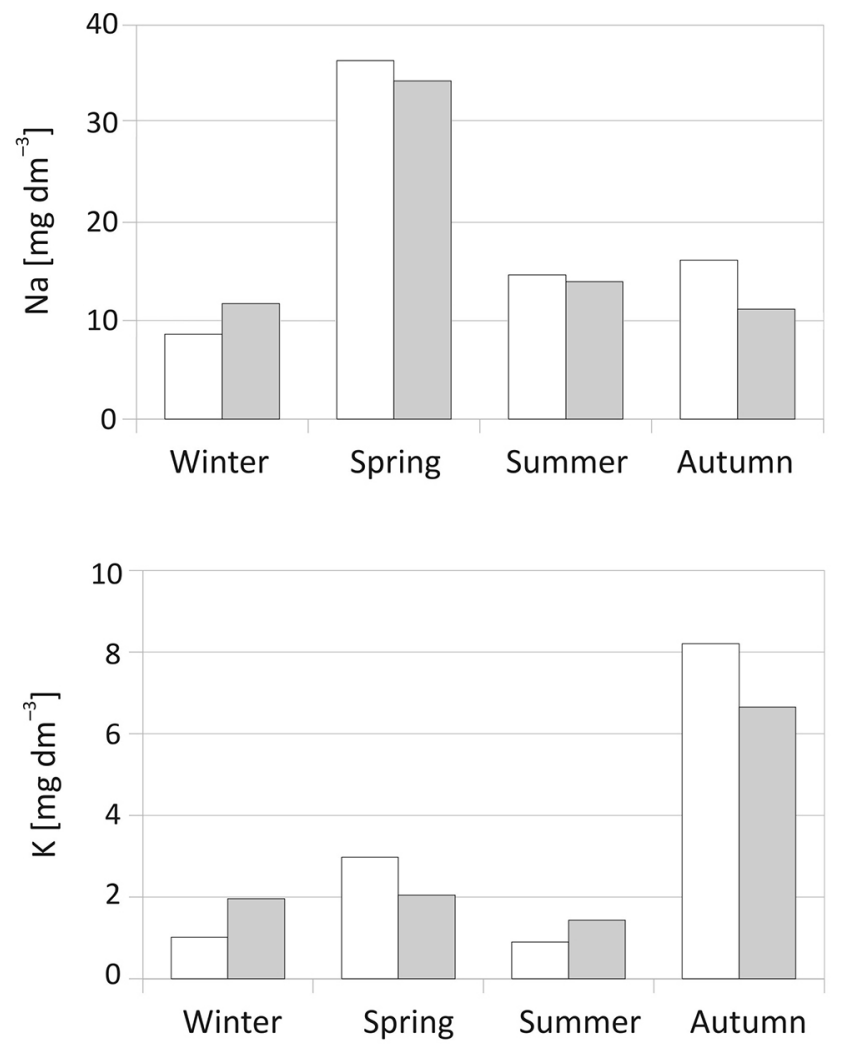

Table 3. Correlations of concentrations of analysed metals between their concentrations in SML and SUB (Spearman, ${ }^{\star}$ Pearson correlations). Correlations given in bold are statistically significant at $\mathrm{p}<0.05$

\begin{tabular}{ccc}
\hline Metal & Pond No. 1 & Pond No. 2 \\
\hline $\mathrm{Na}$ & 0.69 & $0.94^{*}$ \\
\hline $\mathrm{K}$ & 0.49 & 0.77 \\
\hline $\mathrm{Ca}$ & 0.90 & 0.43 \\
\hline $\mathrm{Mg}$ & 0.83 & 0.81 \\
\hline
\end{tabular}

of $\mathrm{K}$ the greatest concentration of this element in both ponds was recorded in the autumn. In the same period a slight $\mathrm{K}$ enrichment was found in $S M L(E F=1.23)$. Calcium concentration was highest in both analysed ponds in the autumn (Fig. 3). In both ponds the concentration of calcium was almost 3 times greater than in the other seasons. Magnesium concentrations in both ponds showed maximum value in the spring and autumn. In the spring $\mathrm{Mg}$ enrichment was recorded in $S M L$ (mean $E F=1.44$ ) in relation to $S U B$.

Table 3 presents analyses of correlation depending on the type of data distribution: the Spearman and Pearson distributions describing correlations between concentrations of the analysed macroelements in $S M L$ and SUB. Recorded correlation coefficients were significant $(\mathrm{p}<0.05)$ between $S M L$ and $S U B$ for $\mathrm{Na}$ and $\mathrm{Mg}$
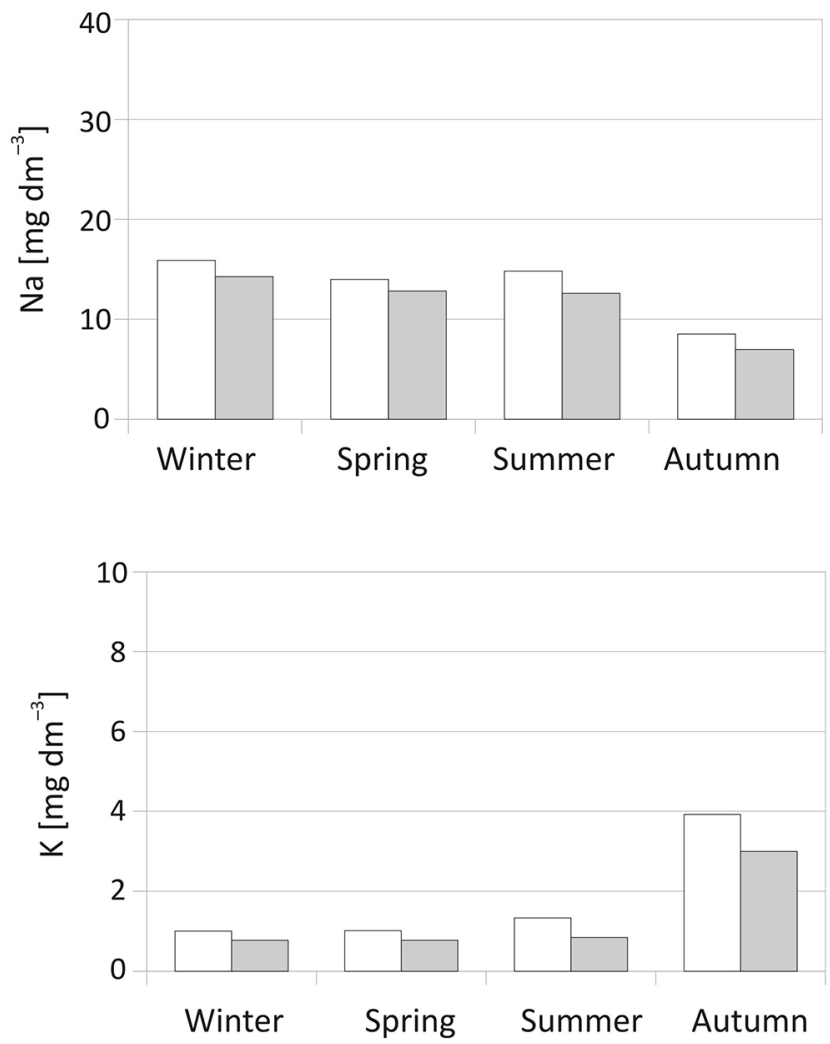

Fig. 2. Seasonal changes in Na and K concentrations in SML (white bars) and SUB (grey bars) of studied ponds (pond No. 1 on the left, pond No. 2 on the right) 

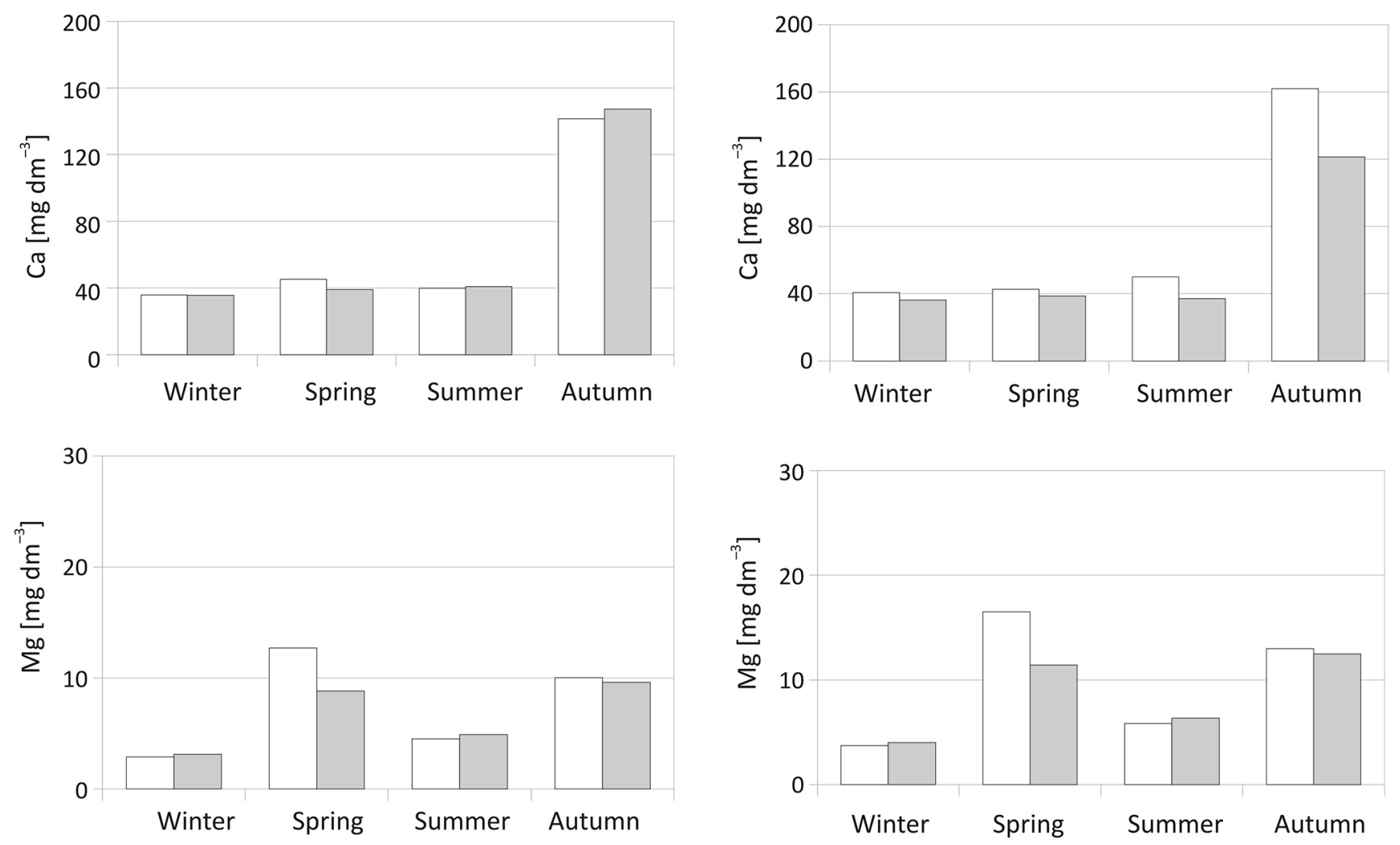

Fig. 3. Seasonal changes in Ca and Mg concentrations in SML (white bars) and SUB (grey bars) of studied ponds (pond No. 1 on the left, pond No. 2 on the right)

in both ponds, while for $\mathrm{K}$ they were significant in pond No. 2 and for Ca in pond No. 1.

\section{Discussion}

Results from world literature show that most chemicals and microorganisms are accumulated in the surface microlayer water at higher concentrations than are is observed in the subsurface layer - this refers to heavy metals (Wurl and Obbard 2004; Antonowicz et al. 2015), biogenic substances (Trojanowski et al. 2001; Mudryk et al. 2003), organic substances (Cincinelli et al. 2001) as well as chlorophyll (Knulst et al. 1997; Antonowicz 2014), bacteria (Estep et al. 1985; Walczak 1998) or viruses (Aller et al. 2005).

In the case of heavy metals concentrations in $S M L$ were found to be even as much as several dozen times greater than in the bulk of the water column. For example, EF for $\mathrm{Pb}$ in Puget Sound in Washington ranged from 26 to 65 (Hardy et al. 1985). The enrichment of heavy metals in SML depends on many factors, including $\mathrm{pH}$, salinity, binding affinities and organic matter composition of the SML (Wurl and Obbard 2004). However, not all metals are capable of accumulating in $S M L$ at much greater concentrations than those observed in SUB. However, based on the re- sults it may be observed that $\mathrm{Ca}$ and $\mathrm{Mg}$ are typically accumulated in $S M L$ in slight amounts in comparison to $S U B$ and if accumulation in $S M L$ takes place, it is frequently a seasonal phenomenon. For example, this may be reflected by studies on the accumulation of calcium and magnesium in Lake Dołgie Wielkie, located at a distance of only approx. $25 \mathrm{~km}$ from the investigated ponds, which showed $E F_{M g}=1.08$ and $E F_{C a}=0.98$ (Antonowicz 2015). The surface microlayer with a thickness ranging from 15.7 to $75 \mu \mathrm{m}$ collected from Lake Skjervatjern showed values of enrichment factors $E F_{C a}$ $=0.9-2.1$ and $E F_{M g}=1.1-1.3$. Similarly, enrichment factors obtained for $\mathrm{Ca}$ during studies conducted seasonally in eutrophic lakes Gardno, Dołgie Wielkie and Jasień were as follows: $E F=1.10-1.11, E F=1.10-1.11$ and $E F=1.07-1.08$ (Antonowicz 2008). In those lakes analyses were also conducted in $S M L$ collected from the thinner layer of $100 \mu \mathrm{m}$. It was found that the obtained factors for $S M L$ with a lesser thickness were slightly greater (Antonowicz 2008, 2015).

No data concerning $\mathrm{Na}$ and $\mathrm{K}$ were found in studied literature, which would confirm the capacity for enrichment for these macroelements in $S M L$ collected with the Garrett net. The only study on the subject is presented in the investigations undertaken by Knulst et al. (1997). The method applied in this study was differ- 
ent, as a teflon cylinder was used which made it possible to collect a thinner $S M L$ closer to the water surface. In view of considerations on the laminar structure of $S M L$, we may observe that thinner SMLs accumulate greater concentrations of heavy metals (Estep et al. 1985; Trojanowski and Antonowicz, 2011). According to data presented by Knulst et al. (1997) recorded for Lake Skjervatjern factors for sodium for SML ranged from 1.0 to 1.1, while for potassium they were found to range from 2.1 to 23 . Only in pond No. 2 was a low enrichment factor for potassium recorded at $E F=1.34$.

One of the causes for the accumulation of metals may be connected with the capacity to bind these macroelements by physical forces such as surface tension, forces of adhesion, cohesion, retention of chemicals in $S M L$ and bioaccumulation in microorganisms (Norkrans 1980; Wurl and Obbard 2004). However, to a lesser extent it is probably connected with deposition from the atmosphere. This is confirmed by statistically significant correlation coefficients between $S M L$ and SUB $(\mathrm{r}=0.69-0.94)$ as well as low concentrations of these elements in the precipitation recorded at the $\mathrm{Hel}$ peninsula: $1.27 \mathrm{mg} \mathrm{Na} \mathrm{dm}^{-3}, 0.38 \mathrm{mg} \mathrm{K} \mathrm{dm}^{-3}, 2.3 \mathrm{mg} \mathrm{Ca}$ $\mathrm{dm}^{-3}, 0.28 \mathrm{mg} \mathrm{Mg} \mathrm{dm}^{-3}$ (Szefer and Szefer, 1986) as well as in data reported by Sapek and Sapek (2011) at 8.24 $\mathrm{mg} \mathrm{Ca} \mathrm{dm}{ }^{-3}$ and $1.58 \mathrm{mg} \mathrm{Mg} \mathrm{dm}^{-3}$.

Analyses of seasonal changes indicate the effect of urban pollutants on transport of substances to $S M L$ and $S U B$ waters in the analysed ponds. It is likely that a significant factor affecting the increase in $\mathrm{Na}$ and $\mathrm{K}$ concentrations in the spring in pond No. 1 included surface run-off (Lis and Pasieczna 1995). Sources of these elements may be salt mixtures applied in the winter for road deicing, which in the spring flow to lower areas, in this case ponds. Mixtures used in the removal of snow and ice most frequently contain $\mathrm{NaCl}$ with such additives as potassium ferrocyanide (Czarna 2013). In the spring we may observe $\mathrm{Mg}$ enrichment in both ponds (mean $E F=1.44$ ), which may be connected with the accumulation of magnesium by the developing phytoplankton and phytoneuston. These microorganisms contain chlorophyll molecules containing magnesium in their cells. In turn, in the autumn the increase in the concentrations of potassium, calcium and magnesium in SML and SUB may be explained by the decomposition of dying organisms and the release of these macroelements to waters.

Recorded concentrations of calcium, magnesium, sodium and potassium in $S U B$ are comparable to those given in literature sources. Calcium content in surface waters of Poland typically falls within the range of $50-150 \mathrm{mg} \mathrm{dm}^{-3}$, while in small water bodies it is 4-66 mg dm${ }^{-3}$ (Lis and Pasieczna 1995). According to data given by Weihsa et al. (2013) collected from 26 lakes mean concentrations ranged from $8.4-62.8 \mathrm{mg} \mathrm{Ca}$ $\mathrm{dm}^{-3}$ and $2.6-25.6 \mathrm{mg} \mathrm{Mg} \mathrm{dm}{ }^{-3}$. According to Lis and Pasieczna (1995) concentration of magnesium in surface waters of Poland was at a minimum of $0.6 \mathrm{mg} \mathrm{dm}^{-3}$, a mean of $11.5 \mathrm{mg} \mathrm{dm}^{-3}$ and in small reservoirs it was $11.8 \mathrm{mg} \mathrm{dm}^{-3}$. Small water bodies contained potassium at $<1 \mathrm{mg} \mathrm{dm}^{-3}$ (mean $9 \mathrm{mg} \mathrm{dm}^{-3}$ ). Orlik and Oboślak (2005) reported mean $\mathrm{K}$ concentration in ponds from 2.0 to $2.1 \mathrm{mg} \mathrm{dm}^{-3}$. Average $\mathrm{Na}$ concentration in inland surface waters of Poland is within the range of $0-50 \mathrm{mg}$ $\mathrm{dm}^{-3}$, small water bodies contain a minimum of $<1$ and a mean of $20 \mathrm{mg} \mathrm{Na} \mathrm{dm}^{-3}$ (Lis and Pasieczna 1995).

\section{Acknowledgements}

The apparatus used in research has been purchased from the project co-financed by the Financial Instrument for Fisheries Guidance and the state budget and Europe Union funds "Creating an innovative center of chemical and biological studies on inland and marine waters at the Agricultural University in Szczecin.

\section{References}

Antonowicz J.P., Mudryk Z., Zdanowicz M., 2015, A relationship between accumulation of heavy metals and microbiological parameters in the surface microlayer and subsurface water of a coastal Baltic lake, Hydrobiol. 762: 65-80.

Antonowicz J., 2008, Quantity of selected physical and chemical parameters in surface microlayers and subsurface water according to example of three lakes. Baltic Coastal Zone, 12: 5-19.

Antonowicz J.P., 2014, Dobowe fluktuacje substancji biogenicznych i chlorofilu w ekotonie: hydrosfera-atmosfera jeziora lobeliowego (Daily fluctuatins of nutrients and chlorpohyll occurrence in the ecotone hydrosphereathmosphere of a lobelia lake), Proc. of ECOpole, 8(2): 465-470 (in Polish, English summary).

Antonowicz J.P. 2015, Capacity to accumulate barium, strontium, calcium and magnesium in the water-air interface of a coastal lake at the Baltic Sea. Baltic Coastal Zone. 19: 23-36.

Aller J.Y., Kuznetsova M.R., Jahns C.J., Kemp P.F., 2005, The sea surface microlayer as a source of viral and bacterial enrichment in marine aerosols, J. Aerosol Sci. 36(5): 801-812.

Cincinelli L.A., Stortini A., Perugini M., Checchini L., Lepsi L., 2001, Organic polutants in sea-surface microlayer and aerosol in the coastal environment of Leghorn - (Tyrrhenian Sea), Mar. Chem. 76: 77-98.

Cunliffe M., Murrell J.C., 2009, The sea-surface microlayer is a gelatinous biofilm, ISME J. 3: 1001-1003.

Czarna M., 2013, Przegląd środków chemicznych stosowanych w zimowym utrzymaniu dróg w Polsce (Overwiew of chemicals applied to winter road maintenance in Po- 
land), Zesz. Nauk. UZ Inż. Środ. 151(31):18-25 (in Polish, English summary).

Estep K., Maki J., Danos S., Remson C., 1985, The retrieval of material from the surface microlayer with screen and plate samples and its implications for partitioning of material within the microlayer, Freshwat. Biol. 15: 15-19.

Garrett W., 1965, Collection of slick forming materials from the sea surface, Limnol. Oceanogr. 10(4): 602-605.

Knulst J., Backlund P., Hessen D., Riise G., Södergren A., 1997, Response of surface microlayers to artificial acid precipitation in a meso-humic lake in Norway, Wat. Res. 31(9): 2177-2186.

Hillbricht-Ilkowska A., Kostrzewska-Szlakowska I., 2004, Surface microlayer in lakes of different trophic status: nutrients concentration and accumulation, Pol. J. Ecol. 52: 461-478.

Kozarec Z.B., Ćosević S., Frka D.M., Hacke S., 2003, Complex methodological approach to the studies of natural microlayers at the air-water interface, Colloids Surf. A Physicochem. Eng. Asp. 219: 173-186.

Lis J., Pasieczna A., 1995, Atlas geochemiczny Polski 1:2 500000 (Geochemical atlas of Poland 1:2 500 000), PIG, Agencja Wyd. A. Grzegorczyk, Warszawa, 34 pp. (in Polish).

Liss P.S., Duce R.A. (eds), 2005, The Sea Surface and Global Change. Cambridge (UK), Cambridge Univ. Press., Cambridge, $536 \mathrm{pp}$.

Luszniewicz A., Słaby T., 2008, Statystyka z pakietem komputerowym STATISTICA PL. Teoria i zastosowania (Statistics from the computer package STATISTICA PL. Theory and applications), Wydaw. C.H. Beck, Warszawa, 472 pp. (in Polish).

Norkrans B., 1980, Surface microlayer in aquatic environments, Adv. Microbiol. Ecol. 4: 51-85.

Mudryk Z., Trojanowski J. Skórczewski P. Antonowicz J., 2003, Chemical and bacteriological studies of surface and subsurface water layers in estuarine Lake Gradno, Pol. J. Environ.Stud. 12: 199-206.

Orlik T., Obroślak R., 2005, Analiza jakości wód w stawie rybnym w zlewni rzeki Giełczwi (Analysis of water quality in fish pond in eroded basin of the Giełczw River), Acta Agrophysica 5(3): 705-710 (in Polish, English summary).
Perkin Elmer Sciex, 2005, Podręcznik użytkownika ELAN Version 3.3 (User manual ELAN Version 3.3) Perkin Elmer/MDS Sciex Instrument, $534 \mathrm{pp}$.

Sapek B., Sapek A., 2011, Wapń i magnez w opadzie atmosferycznym (Calcium and magnesium in atmospheric deposition) IOŚ-PIB, Ochr. Środ. Zas. Nat. 50: 134-155 (in Polish).

Sieburth J. McN., 1983, Microbiological and organic-chemical processes it the surface and mixed layer [in:] Liss P.S., Slinn W.G.N. (eds), Air-Sea Exchange of Gases and Particles, Reidel Publishing Co., Hingham: 121-172.

StatSoft, Inc., 2012. STATISTICA (data analysis software system) version 12, www.statsoft.com.

Szefer P., Szefer K., 1986, Some metals and their possible sources in rain water of the southern Baltic coast, 1976 and 1978-1980, Sci. Total. Environ. 57: 78-89.

Szefer P., 1990, Mass-balance of metals and indentification of their sources in both river and fallout fluxes near Gdańsk Bay, Baltic Sea, Sci. Total Environ. 95: 131-139.

Trojanowski J., Antonowicz J., 2011: Heavy metals in surface microlayer in water of lake Gardno. Arch. Environ. Prot., $37,75-88$

Trojanowski J., Trojanowska C., Korzeniewski K., 1990, Warunki hydrochemiczne $\mathrm{w}$ jeziorach przymorskich (Hydrochemical conditions in the coastal lakes), Słupskie Pr. Mat.-Przyr. 8B: 123-160 (in Polish).

Trojanowski J., Trojanowska C., Antonowicz J., 2001, Nitrogen and phosphorus in surface microlayers of the lake Gardno. Ecohydrol. \& Hydrobiol., 1, 457-453.

Walczak M., 2008, Impact of solar radiation, including UV, on the activity of intra- and extracellular bacterial enzymes from the surface microlayer, Pol. J. Natur. Sci. 23(2): 415-427.

Weihsa S., Pełechaty M., Pukacz A., 2013, Charophyte occurrence in phytocoenoses of Typhetum angustifoliae association in lakes of Ziemia Lubuska (mid-Western Poland), Stud. Limnol. Telmatol. 7: 3-12.

Wurl O., Obbard J.P., 2004, A review of pollutants in the seasurface microlayer $(S M L)$ : a unique habitat for marine organisms, Mar. Poll. Bull. 48: 1016-1030. 